\title{
Agronomic Evaluation of Mustard (Brassica juncea L.) Hybrids under Agroclimatic Conditions of Prayagraj (U.P.) in Rabi- 2019-2020
}

\author{
Tarun Thakur ${ }^{1 *}$, Vikram Singh ${ }^{1}$, Sujeet Kumar ${ }^{2}$, \\ Dhananjay Tiwari ${ }^{1}$ and Manoj Paul Thakur ${ }^{1}$ \\ ${ }^{I}$ Department of Agronomy, Naini Agricultural Institute, Sam Higginbottom University of \\ Agriculture, Technology and Sciences Prayagraj, Uttar Pradesh, India \\ ${ }^{2}$ Scientific Officer Upcar (Lucknow), India \\ *Corresponding author
}

\begin{tabular}{|c|c|}
\hline & A B S T R A C T \\
\hline Keywords & \multirow{4}{*}{$\begin{array}{l}\text { The Agronomic investigation entitled Agronomic evaluation of Mustard (Brassica } \\
\text { juncea L.) hybrids under agroclimatic conditions of Prayagraj (U.P.) was carried } \\
\text { out during Rabi } 2019-2020 \text {. The field experiment was laid out in Randomised } \\
\text { Block Design, replicated four having } 5 \text { different variety as treatments. The finding } \\
\text { of the experiment indicated that the growth parameters of } 45 \mathrm{~S} 35 \text { (Mustard) viz. } \\
\text { Plant height }(169.02 \mathrm{~cm}) \text {, Primary Branch/plant }(8.5) \text {, Dry weight }(37.0 \mathrm{~g}) \text { and } \\
\text { CGR }\left(12.405 \mathrm{~g} / \mathrm{m}^{2} / \text { day). as well as yield attributes like Number of siliqua/plant, }\right. \\
(372 / \text { plant), Grain/siliqua (14.55), Test weight } 5.85(\mathrm{~g}) \text {, Grain yield }(1955 \mathrm{~kg} / \mathrm{ha}) \\
\text { and Harvest index (36.96\%) were also higher in } 45 \mathrm{~S} 35 \text {. The genotype } 45 \mathrm{~S} 35 \text { was } \\
\text { found to be the best for growing because it was found to be more productive (1955 } \\
\mathrm{kg} / \mathrm{ha} \text { ) as well as economic }(1.61) \text {. }\end{array}$} \\
\hline $\begin{array}{l}\text { Mustard, BULLET, } \\
\text { 45S35, 1604, } \\
\text { 45S46, ANMOL, } \\
\text { Hybrid, Yield }\end{array}$ & \\
\hline Article Info & \\
\hline $\begin{array}{l}\text { Accepted: } \\
07 \text { December } 2020 \\
\text { Available Online: } \\
10 \text { January } 2021\end{array}$ & \\
\hline
\end{tabular}

\section{Introduction}

Brassica juncea L. originally introduced from China into north east India, from it has extended into Afghanistan via the Punjab. Eastern Afghanistan, together with the adjoining north western India, is one of the independent centre of origin of Brown sarson (Brassica compestris var. brown sarson). In India the Brassica crops occupy the second largest position after groundnut, with 3.5 million hectares, production about 2 million tonnes of seed annually. The chief states producing them are Uttar Pradesh, Punjab, Haryana, Assam, Bihar, Madhya Pradesh,
Rajasthan, West Bengal, and Orissa. The production of rape seed in India is around 16.2 million tonnes which accounts for about 18 percent of the total oilseed production of the country. In U.P., rapeseed and mustard is one of the major grown crop occupying 0.56 million ha of area, with production and productivity of 0.699 million tonnes and 1248 $\mathrm{kg} / \mathrm{ha}$ respectively [(India Statistics (Indiastat.com) (2014-15)]. Rapeseedmustard is the third most important source of edible oil next to soybean and groundnut in India, and is grown in certain tropical and subtropical regions as a cold-season crop (Shekhawat et al., 2012). The seed and oil of 
mustard have a peculiar pungency due to presence of glucosinolate and its hydrolysis products such as allyl isothiocynate (0.30$0.35 \%)$.

\section{Materials and Methods}

The experiment was conducted during the Rabi season of 2019 at the Crop Research Farm, Department of Agronomy, Sam Higginbottom University of Agriculture, Technology and Sciences, Prayagraj (U.P). The Crop Research Farm is situated at $25^{\circ} 39^{\prime}$ 42 " N latitude, $81^{\circ} 67^{\prime} 56^{\prime}$ ' E longitude and at an altitude of $98 \mathrm{~m}$ above mean sea level. The soil was sandy loam in texture, low in organic carbon $(0.15 \%)$ and medium in available nitrogen $(35.55 \mathrm{~kg} / \mathrm{ha})$, phosphorus $(9.8 \mathrm{~kg} / \mathrm{ha})$ and low in potassium (187.2 $\mathrm{kg} / \mathrm{ha}$ ). The climate of the region is semi arid subtropical. The experiment was laid out in Randomized Block Design replicated four. Recommended dose of fertilisers was applied with Urea, SSP,MOP. Seeds were sown at a spacing of $45 \mathrm{~cm}$ X $10 \mathrm{~cm}$.

\section{Chemical analysis of soil}

Collected soil samples were analysed for organic carbon by rapid titration method (Sparks, 1996), available nitrogen was estimated by alkaline permanganate method by (Subbiah and Asija, 1956) available phosphorous by Olsen's method as outlined by (Jackson, 1967), available potassium was determined by extracting with neutral normal ammonium acetate solution and estimating by using flame photometer (ELICO model) as outlined by (Jackson, 973).

\section{Statistical analysis}

Experimental data collected was subjected to statistical analysis by adapting Fisher's method of analysis of variance (ANOVA) as outlined by (Gomez and Gomez, 1984). Critical differences (CD) were calculated with F-test was found significant at 5\% level.

\section{Results and Discussion}

\section{Germination (\%)}

As observation data show that there is medium percentage of more than $70 \%$ in all hybrids of Mustard (Brassica juncea L.). In T2 (45S35), T5 (ANMOL), T3 (1604) and T4 (45S46) these variety have between 70 to 90 $\%$ germination. The highest germination $\%$ (96\%) was observed in T1 (BULLET).

\section{Plant height (cm)}

At 100 DAS the significant and higher plant height $(169.02 \mathrm{~cm})$ was found in T2 [45S35]. However, T5 [ANMOL] and T4 [45S46] found to be statistically at par with T2 [45S35].

Height of a plant is determined by genetical character and under a given set of environment different variety will acquire their height according to their genetical make up. Das et al., (2019). Similar finding are observed by Dongarkar et al., (2005)

\section{Number of primary branches}

At 100 DAS the significant and higher Number of primary branches (8.5) was found in $\mathrm{T} 2$ [45S35]. However, treatment $\mathrm{T} 1$ [BULLET] and T5 [ANMOL], found to be statistically at par with T2 [45S35]. Different varieties of mustard had significant influence on flowering characters at productive part flowering developments stages which might be due to different crop growth maturity pattern in complete life cycle growth period (Kumar et al., 2017).

Higher number of branches/plant is the result of genetic makeup of the crop and environmental conditions which play a remarkable role towards the final seed yield of the crop (Helal et al., 2016). 
Table.1 Effect of different hybrids on germination, growth, yield attributes, yield and economics of Mustard

\begin{tabular}{|c|c|c|c|c|c|c|c|c|c|c|c|c|c|}
\hline $\begin{array}{l}\text { TREATMENT } \\
\text { DETAILS }\end{array}$ & $\begin{array}{c}\text { Germination } \\
(\%)\end{array}$ & $\begin{array}{l}\text { Plant } \\
\text { height } \\
(\mathrm{cm})\end{array}$ & $\begin{array}{c}\text { Number of } \\
\text { Primary } \\
\text { Branches/Plant }\end{array}$ & $\begin{array}{c}\text { Number of } \\
\text { Secondary } \\
\text { Branches/Plant }\end{array}$ & $\begin{array}{c}\text { Plant } \\
\text { dry } \\
\text { weight } \\
\text { (g) }\end{array}$ & $\begin{array}{l}\text { No. of } \\
\text { Siliqua } \\
\text { /plant }\end{array}$ & $\begin{array}{l}\text { Length } \\
\text { of } \\
\text { Siliqua } \\
\text { (cm) }\end{array}$ & $\begin{array}{c}\text { Seeds } \\
\text { /Siliqua }\end{array}$ & $\begin{array}{c}\text { Test } \\
\text { Weight } \\
\text { (g) }\end{array}$ & $\begin{array}{c}\text { Seed } \\
\text { Yield } \\
\text { (Kg/ha) }\end{array}$ & $\begin{array}{l}\text { Biological } \\
\text { Yield } \\
\text { (Kg/ha) }\end{array}$ & $\begin{array}{c}\text { Harvest } \\
\text { index } \\
(\%)\end{array}$ & $\begin{array}{c}\text { B:C } \\
\text { Ratio }\end{array}$ \\
\hline BULLET & 96 & 153.86 & 8.30 & 12.45 & 32.55 & 328.05 & 5.21 & 14.30 & 5.27 & 1917.5 & 6250.0 & 34.96 & 1.67 \\
\hline $45 \mathrm{~S} 35$ & 72 & 169.02 & 8.50 & 13.10 & 37.00 & 372.80 & 5.47 & 14.35 & 5.85 & 1935.0 & 6500.0 & 36.95 & 1.69 \\
\hline 1604 & 84 & 157.09 & 7.75 & 9.97 & 29.00 & 288.20 & 4.95 & 12.65 & 4.35 & 1177.5 & 4375.0 & 21.82 & 1.03 \\
\hline $45 \mathrm{~S} 46$ & 88 & 158.44 & 8.02 & 10.30 & 30.82 & 317.35 & 4.99 & 13.05 & 4.68 & 1415.0 & 5250.0 & 26.92 & 1.24 \\
\hline ANMOL & 76 & 166.81 & 8.12 & 11.65 & 32.10 & 322.35 & 5.00 & 14.05 & 5.15 & 1692.5 & 5500.0 & 27.25 & 1.47 \\
\hline F-test & - & S & S & S & S & $\mathrm{S}$ & NS & S & S & $\mathrm{S}$ & $\mathrm{S}$ & $\mathrm{S}$ & - \\
\hline Sem & - & 3.46 & 0.15 & 0.28 & 1.45 & 11.37 & 0.13 & 0.19 & 0.07 & 35.36 & 232.64 & 0.98 & - \\
\hline $\mathrm{CD}(\mathrm{P}=0.05)$ & - & 10.77 & 0.47 & 0.88 & 4.53 & 35.44 & - & 0.61 & 0.23 & 110.96 & 724.79 & 3.06 & - \\
\hline
\end{tabular}




\section{Number of secondary branches}

At 100 DAS the higher and significant Number of Secondary Branches (13.1) was observed in $\mathrm{T}_{2}$ [45S35]. However, treatment $\mathrm{T}_{1}$ [BULLET], found to be statistically at par with $\mathrm{T}_{2}$ [45S35]. Different varieties of mustard had significant influence on flowering characters at productive part flowering developments stages which might be due to different crop growth maturity pattern in complete life cycle growth period (Kumar et al., 2017).

Higher number of branches/plant is the result of genetic makeup of the crop and environmental conditions which play a remarkable role towards the final seed yield of the crop (Helal et al., 2016).

\section{Plant Dry Weight (g)}

At 100 DAS the significant and higher plant dry weight $(37.0 \mathrm{~g})$ was found in T2 [45S35]. However treatment T1 [BULLET], found to be statistically at par with T2 [45S35]. At 20 DAS higher plant dry weight $(0.35 \mathrm{~g})$ was found in T1 [BULLET] through Nonsignificant. Similar finding given by Patel et al (2017).

\section{Days to 50\% flowering and Days to maturity}

The significant variation in 50\% flowering may be due to different genotype. However the significant and minimum days taken for $50 \%$ flowering was in treatment T4 [45S46] 42.5 days while treatment T3 [1604] and T5 [ANMOL] was at par with T4.

The significant variation in Days taken for maturity may be due to different genotype. However the significant and minimum days taken for maturity was in treatment $\mathrm{T} 4$ [45S46] 102.25 days while treatment T3 [1604] and T5 [ANMOL] was at par with T4.

\section{No. of siliqua/plant}

The data showed significant and higher no. of siliquae / plant (372.8) in Treatment $\mathrm{T}_{2}$ [45S35] which was most significant among all the other treatments.

\section{Length of siliqua $(\mathrm{cm})$}

The data showed significant and higher no. of grain/siliquae (14.35) in T2 [45S35]. However treatments T1 [BULLET] and T5 [ANMOL] found to be statistically at par with T2 [45S35]. Production of higher yield by different varieties might be due to the contribution of cumulative favorable effects of the crop characteristics viz., number of branches/plant, silique/plant and seeds/siliqua. Helal et al., (2016)

\section{Grains/siliqua}

The data showed maximum length of siliquae $(5.47 \mathrm{~cm})$ was found in $T_{2}$ [45S35] though Non-significant.

\section{Test weight (g)}

The data showed significant and maximum test weight $(5.85 \mathrm{~g})$ was observed in $\mathrm{T}_{2}$ [45S35] among all the treatments.

\section{Seed yield $(\mathrm{kg} / \mathrm{ha})$}

The data showed significant and maximum seed yield (1935.0 kg/ha) was observed in T2 [45S35]. However, T1 [BULLET] found to be statistically at par with T2 [45S35].All the growth and yield attributes which determined the seed yield of mustard crop, were adversely influence when the different nutrient management practise adopted, which might be resulted to poor growth and translocation of photosynthates from source to sink and ultimately lower yield was recorded. Kour et al (2017). 


\section{Biological yield (kg/ha)}

The data showed significant and maximum biological weight $(6500.0 \mathrm{~kg} / \mathrm{ha})$ was observed in T2 [45S35]. However, treatment T1 [BULLET] found to be statistically at par with T2 [45S35]. As discussed earlier, the different hybrids have different yield potential, which is the reason for yield variation among different varieties. In contrast to the traditional OP varieties hybrids have bigger canopy structure and to explore optimum yield potential these hybrids needs wider spacing in comparison to OP varieties (Das et al., 2019).

\section{Harvest index (\%)}

The data showed significant and maximum harvest index (36.95) was observed in $\mathrm{T}_{2}$ [45S35]. However, treatment $\mathrm{T}_{1}$ [BULLET] found to be statistically at par with $\mathrm{T}_{2}$ [45S35].The highest biological yield might be on account of maximum seed yield than the other varieties (Das et al., 2019).

\section{Economic analysis}

The Maximum gross return ( $₹$ 91640/ha), the highest net return ( $₹$ 37317/ha), Maximum benefit cost ratio of 1.69 was obtained from treatment T2 (45S35).

\section{Acknowledgement}

The authors are sincerely thankful to Department of Agronomy, Naini Agricultural Institute, SHUATS, Prayagraj for providing field, facilities and assistance in conducting this research.

\section{References}

Dongarkar K. P., Pawar W. S., Khawale V. S., Khutate N. G. and Gudadhe N. N. (2005). Effect of nitrogen and sulphur on growth and yield of mustard (Brassica juncea L.). J Soils Crops 15: 163-67.

India Statistics (Indiastat.com). (2014-15).

Kour S., Gupta M., Kachroo D. and Bharat R. (2017). Direct and Residual Effect of Zinc and Boron on Productivity, Nutrient Uptake and Quality on Mustard (Brassica juncea) and Succeeding Maize (Zea mays) in Subtropical Inceptisols of Jammu. Journal of the Indian Society of Soil Science, Vol. 65, No. 3, pp 334-340.

Kumar A., Mahapatra B.S., Singh V.P., Shukla A., Negi M.S., Yadav A. S., Singh P., Gaurendra G. and Singh M. (2017). Effect of nutrient levels on yield, nutrient uptake and economics of Indian mustard (Brassica juncea) in tarai region of Uttarakhand. Indian Journal of Agronomy 62 (3): 378-381.

Patel A., Singh A. K, Vendra S. S., Alekh S., Nikhil R. and Singh A. K. (2017). Effect of Different Sowing Dates on Growth, Yield and Quality of Various Indian Mustard (Brassica juncea L.) Varieties. Int.J.Curr.Microbiol.App.Sci Special Issue-4: 71-77

Shekhawat, K., Rathore, S. S., Premi, O. P., Kandpal, and Chauhan, J. S., (2012). Advances in agronomic management of Indian mustard (Brassica juncea (L.) Czernj. Cosson): An overview. International Journal of Agriculture. 2012: $1-14$.

\section{How to cite this article:}

Tarun Thakur, Vikram Singh, Sujeet Kumar, Dhananjay Tiwari and Manoj Paul Thakur. 2021. Agronomic Evaluation of Mustard (Brassica juncea L.) Hybrids under Agroclimatic Conditions of Prayagraj (U.P.) in Rabi- 2019-2020. Int.J.Curr.Microbiol.App.Sci. 10(01): 347-351. doi: https://doi.org/10.20546/ijcmas.2021.1001.043 